\title{
Mark and Matthew II
}

\author{
Comparative Readings: Reception History, Cultural Hermeneutics, and Theology \\ Ed. by Eve-Marie Becker and Anders Runesson
}

[Markus und Matthäus II. Vergleichende Analysen: Rezeptionsgeschichte, Kulturhermeneutik und Theologie.]

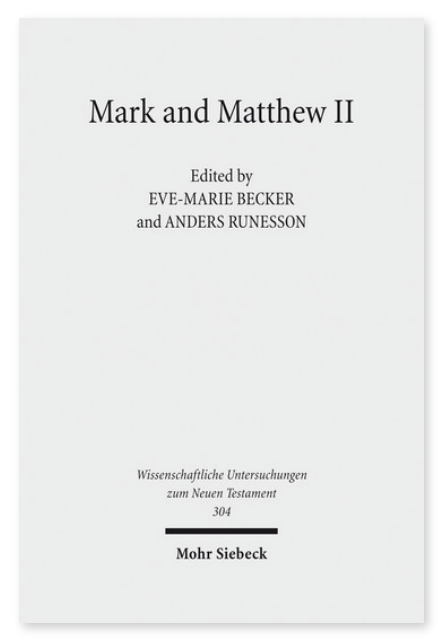

2013. VIII, 418 Seiten. WUNT I 304

ISBN 978-3-16-152546-9 DOI 10.1628/978-3-16-152546-9 eBook PDF $159,00 €$

ISBN 978-3-16-152545-2 Leinen $159,00 €$
Veröffentlicht auf Englisch.

Die vorliegende Aufsatzsammlung geht von einem multi-perspektivisch gewählten vergleichenden Ansatz aus, um die Rezeption des Markus- und des Matthäus-Evangeliums in verschiedenen Auslegungskontexten des 1. bis 21. Jahrhunderts aufzuzeigen. Der Schwerpunkt liegt dabei auf Kulturhermeneutik und Theologie. Es wird hierbei besonders die Dynamik der Textinterpretation beleuchtet, die durch die Anwendung der hermeneutischen Parameter wie Geschichte, Religion und Politik im Zuge der Applikation der Texte für die jeweiligen Verstehenskontexte der Interpreten entsteht. Der vorliegende Band stellt den zweiten Teil eines größeren komparativen Projektes dar, das sich der vergleichenden Analyse der beiden frühesten Evangelien widmet - die Beiträge des ersten Bandes (WUNT 271, 2011) untersuchen vor allem die Entstehungsgeschichte der Evangelien im 1. Jh. n.Chr.

Mit Beiträgen von: Janice Capel Anderson, Eve-Marie Becker, Adela Yarbro Collins, Detlev Dormeyer, René Falkenberg, Michael Knowles, Hans Leander, Petri Luomanen, Martin Meiser, Mogens Müller, Todd Penner, Anders Runesson, Caroline Vander Stichele, Joseph Verheyden, Benedict Viviano, Stephen Westerholm, Peter Widdicombe

Inhaltsübersicht

Preface Anders Runesson/Eve-Marie Becker: Introduction: Reading Mark and Matthew Within and Beyond the First Century PART IReception and Cultural Hermeneutics: Reading Mark and Matthew From the 1st to the 21st Century Eve-Marie Becker: The Reception of »Mark« in the 1st and 2nd Centuries CE and its Significance for Genre Studies - Petri Luomanen: From Mark and Q to Matthew: An Experiment in Evolutionary Analysis - Benedict Viviano: Who Wrote Q? The Sayings Document (Q) as the Apostle Matthew's Private Notebook as a Bilingual Village Scribe (Mark 2:13-17; Matt 9:9-13) - René Falkenberg: Matthew 28:16-20 and the Nag Hammadi Library: Reception of the Great Commission in the Sophia of Jesus Christ - Peter Widdicombe: The Patristic Reception of the Gospel of Matthew: The Commentary of Jerome and the Sermons of John Chrysostom - Joseph Verheyden: Reading Matthew and Mark in the Middle Ages: The Glossa Ordinaria - Martin Meiser: Protestant Reading of the Gospels of Mark and Matthew in the 20th Century - Detlev Dormeyer: A Catholic Reading of the Gospels of Mark and Matthew in the 20th Century - Anders Runesson: Judging the Theological Tree by its Fruit: The Use of the Gospels of Mark and Matthew in Official Church Documents on Jewish - Christian Relations PART IIHistory, Meaning, and the Dynamics of Interpretation Adela Yarbro Collins: Mark and the Hermeneutics of History Writing - Stephen Westerholm: Hearing the Gospels of Matthew and Mark - Mogens Müller: The Place of Mark and Matthew in Canonical Theology: A Historical Perspective - Janice Capel Anderson: Mark and Matthew in Feminist Perspective: Reading Matthew's Genealogy - Hans Leander: Mark and Matthew after Edward Said - Todd Penner/Caroline Vander Stichele: Re-Assembling Jesus: Rethinking the Ethics of Gospel Studies Michael Knowles: The Interpretation of Mark and Matthew in Historical Perspective: The Transfiguration as a Test Case

Eve-Marie Becker Geboren 1972; 2001 Dr. theol.; 2004 Habilitation; 2006-18 Professorin für neutestamentliche Exegese an der Universität Aarhus/Dänemark; 2016-17 Distinguished Visiting Professor of New Testament an der Emory University in Atlanta/USA; seit 2018 Professorin für Neues Testament an der Westfälischen Wilhelms-Universität Münster. https://orcid.org/0000-0002-0398-6448

Anders Runesson Born 1968; 2001 PhD; 2002 Docent, Lund University, Sweden; 2003-15 Professor of Early Christianity and Early Judaism, McMaster University, Canada; since 2015 Professor of New Testament in the Faculty of Theology at the University of Oslo, Norway.

https://orcid.org/0000-0001-6042-0101

Jetzt bestellen:

https://mohrsiebeck.com/buch/mark-and-matthew-ii-9783161525469?no_cache=1

order@mohrsiebeck.com

Telefon: $+49(0) 7071-923-17$

Telefax: +49 (0)7071-51104 